\title{
Et Optrin i Tirslund Kirke
}

\section{Af F. Elle Jensen.}

Det er en kendt Sag, at Kirken og hvad dermed stod i Forbindelse, i ældre Tid omfattedes med en vis sky Ærefrygt i de brede Lag. Forestillinger, der oprindelig havde været forbundet med den gamle hedenske Helligdom, var nemlig ubevidst blevet overført paa den, saa den for Almuen nu ikke blot var det Hus, hvor Gud dyrkedes om Søndagen, men ogsaa Stedet, hvor mægtige og overnaturlige Kræfter boede, knyttet saavel til selve Bygningen som dens Inventar, og som, om de benyttedes ret, kunde tages i Menneskets Tjeneste til Værn mod Sygdomme og onde Aander. Klokkens Rust, Vinduernes Bly, Kirkegaardens Muld, Altervinen, Daabsvandet, Trevler af Kristentøjet o. a. ansaas for at have magiske Virkninger, fordi det altsammen havde været i Forbindelse med den viede Helligdom og derfor troedes i Stand til at meddele Brugeren noget af dennes løndomsfulde Kraft.

Det er da sikkert ogsaa en tilsvarende Opfattelse, der ligger til Grund for den Tildragelse i Tirslund Kirke i 1766, som nedenfor skal skildres. Dens Forløb gengives her - med moderniseret Retskrivning - med Præstens, Hr. Gutfelds, egne Ord i hans Indberetning derom til Biskop Bloch i Ribe.

Højædle, højærværdige Hr. Biskop!

Herved maa jeg nødes til at indberette den forskrækkelige, overtroiske Gerning, som i Dag d. 4. Søndag efter Paaske skete udi Tirslund Kirke, og tillige allerydmygst bede, at den tilstedeværende Menighed, som saa igennem Fingre med og ej forhindrede, men meget mere samtykte denne forargelige og fordam- 
melige Gerning, derfor efter Sagens Beskaffenhed maatte ifølge . kongel. allernaadigst Lov og Forordning vorde anset straffet.

Efter at jeg i Dag, da Prædiken var til Ende, havde vendt mig om til Alteret for at konsekrere Brødet og Vinen til Sakramentets hellige Brug, og de første Gæster allerede havde sat sig ned for Alteret, saa just da jeg messer paa den første Bøn i Fadervor, hører jeg bag mig en usædvanlig Hvisken og Mumlen, som immer blev stærkere og bestod af disse Ord: „O Jøsses, Jøsses!“ Jeg vendte derpaa Hovedet til den højre Side for at se efter Aarsagen til saadan usædvanlig Alarm, men saa intet uden at Folkene paa begge Sider i Kirken rakte Hoveder i Vejret og kigede med en stor Forundring; i det samme hører jeg ved den venstre Side tæet ved mig en uformodentlig Mumlen, og da jeg vender Hovedet derom, ser jeg til min storste Angst og Forfærdelse en Dreng af omtrent 14 Aars Alder splitternøgen, som kaster sin Haand et Par Gange paa Alteret og hastig udsiger disse Ord: „Jeg kan ikke ligge tør, jeg kan ikke ligge tør.“ Han tog derpaa sin Vej tilbage igen lige over Tralværket, da et Par af Kommunikanterne stod godvillig op for at give ham Rum til desto bedre at skræve derover. Hvorpaa han stiltiende forføjede sig ned ad Kirken igen og søgte ud ad Døren, uden at noget Menneske i den snævre og eneste Kirkegang enten havde forment ham Opgangen til eller Nedgangen fra Alteret. I denne store Forvirring fattede jeg mig dog saa vidt, at jeg raabte til Menigheden disse Ord: „Hvorfor tillader I, at slig en ugudelig Karl skal komme ind at forstyrre vor Andagt og bespotte Herrens Helligdom? Grib ham dog, at Sagen han oplyses, hvem han hører til, at baade han og de kan faa deres velfortjente Straf!" Derpaa rejser en af Kommunikanterne ved Navn Lars Smed af Aabøl sig op, rækker Hovedet over til mig og med en maadelig Lyd siger disse Ord: „Hr. Vater! Han skal ikke alterere sig derover, det er ikkuns en Dreng, som ikke kan ligge tør om Natten og derfor haver brugt dette Raad; det er set ligesaa tilforn med en i Hellevad Kirke." Da jeg derpaa igentog min Ben til Menigheden, at nogle af dem dog vilde gaa ud og paagribe denne ugudelige Dreng, rejser sig den ene Kirkeværge, navnlig 
Morten Hansen af Aabøl, tillige med en Mand, navnlig Hans Hansen af Gottrup, og gaar ud af Kirken. Derpaa bad jeg Menigheden i Herrens Navn at være stille, da jeg igen vilde fortsætte Gudstjenesten, som ogsaa ved vor Herres Naade skete, men Gud ved bedst, med hvad for en Angst, Forbavselse og Skælven paa min Side, som aldrig tilforn havde hørt af sligt et fordømmeligt, overtroisk Raad at sige.

Da Kommunionen var forbi, og jeg vender mig om for at lyse Velsignelsen, ser jeg, at de tvende udgangne Mænd igen var indkommet i Kirken, hvorpaa jeg, da Degnen tilsidst havde bedt i Kordøren, træder ned paa Kirkegulvet og spørger Menigheden ad, hvorfra den Dreng var, men ingen efter deres Gensvar kendte ham, og ingen af de da tilstedeværende (thi mange var allerede under den sidste Salmes Sjungen udløben af Kirken) vilde kende ham, da han dog som en Dreng af et fremmed Sogn maa hos en eller anden af Menighedens Lemmer nødvendig have faaet at vide, at der just i Dag skulde holdes Altergang i den Kirke. Jeg spurgte derpaa de tvende forbem. Mænd, hvorfor de ikke havde grebet ham, men de svarede ganske kort, især Morten Hansen, at de vel havde set ham sidde og klæde sig paa igen, og at der var et voksent Kvindfolk med ham, og at begge tog Vejen henad Ørderup i Toftlund Sogn, men at de tvende Mænd ikke vilde have med ham at gøre og ej holdt det fornødent at paagribe ham.

Jeg spurgte dernæst, hvorfor ingen af Menigheden havde hindret ham fra at løbe op til Alteret, om Helligdommen i det nye Testamente ej $i$ det mindste burde holdes lige saa hellig og bevogtes lige saa nøje som Helligdommen i det gamle. Nogle undskyldte sig derpaa med Forundring og Angst, andre med Uvidenhed med hans Ærinde, men de fleste, desværre forblindede af Mørkets Fyrste, holdt hemmeligen med denne fordømmelige Overtro og ansaa det for en Barmhjertighedsgerning, at de hverken med Haand eller Mund havde hindret ham fra at betjene sig af det Raad, som han stiltiende skulde bruge. Jeg forsikrede derpaa, at jeg skulde melde det til hans Højærværdighed Biskoppen at forestille denne græsselige Gerning paa 
højere Steder, for i Fremtiden at forebygge sligt et ugudeligt og forargeligt Foretagende, hvorimod Menigheden bad mig i hverandres Munde, at jeg ikke skulde forivre mig; det havde ej saa meget paa sig. De kendte ikke Drengen eller Kvinden, som var med ham, men kunde nok se, at han søgte Raad, fordi han ikke kunde ligge tør om Natten.

Dette er Sagen i sin hele Sammenhæng, hvilken jeg med et bedrøvet Hjerte og sygt Legeme haver opsat, medens den var mig i frisk Minde. Nu beder jeg tillige underdanigst, at Deres højædle Højærværdighed derudi vilde udvikle og foranstalte alting til Guds $2 E r e$, til Menighedens Bedste og til dens Tjeneres fornødne Ro og Sikkerhed i deres hellige, ja helligste Embeds Forretninger, ligesom jeg og underdanigst maa udbede mig Deres højædle Højærværdigheds gunstige Dispensation eller og formedelst Deres højformaaende Forestilling og Forbøn hos hans kongl. Majestæt en allernaadigst Dispensation fra at holde Altergang i Tirslund Kirke, da Sognets Lemmer meget vel kan gaa til Hovedkirken, saa længe indtil ved Guds Naade overvindes den store Angst og Frygt, som nu virkelig haver fyldt mit Hjerte og kommer mig til at skælve, saa ofte jeg tænker paa eller ser Alteret [i] Tirslund Kirke, og Sikkerheden for Guds Tjenere i Herrens Templer langt stærkere omgærdes og indskærpes end hidindtil, i Særdeleshed paa Landet, brugeligt haver været.

I det allerydmygste tilforladelige Haab om en vis og beskærmende Bønhørelse forbliver jeg stedse med den allerstørste \#rbedighed

Deres højædle Højærværdigheds

underdanigste Tjener

og alvorlige Forbeder

Bevtoft Pr. Gaard,

d. 27. April 1766.

$$
\text { P. Gutfeld.') }
$$

I en Følgeskrivelse erklærer Gutfeld, at han aldrig havde

1) N. Rangstrup Herredspakke $1586 \mathrm{ff}$, Ribe Bispeark (Landsark. Aabenraa). 
troet, at Overtroen var saa stor i hans Anneks, som han nu til sin store Græmmelse har set. Han gentager desuden sin Bøn til Biskoppen om Hjælp til at bekæmpe den her og andetsteds samt om, at han maa blive dispenseret fra at holde Altergang i Tirslund, til der er truffet Anstalter til at sikre Guds Dyrkelse, og hans Hjerteangst har fortaget sig, thi han er bange, naar han tænker paa Alteret, og kan derfor ikke administrere Nadveren med saa stor Agtsomhed, som han bør. Han har den guddommelige Naade at takke for, at han ikke har forløbet sig.

Biskoppen maa ogsaa være bleven i høj Grad altereret over det passerede, for han svarede omgaaende, ${ }^{2}$ ) at den skændige og forargelige Gerning skulde anmeldes for Amtmand Klingenberg i Haderslev jo for jo heller til Sagens Opklaring og den skyldiges Afstraffelse. Han onskede oplyst, hvor Drengen var fra, og om han var konfirmeret, saa han kunde undersøge, om der kunde anvendes Kirketugt i dette Tilfælde. Men Præstens Bøn om Dispensation kunde han ikke imødekomme; derimod raadede han ham til at faa Nabopræsterne til at vicariere for sig en Tid.

14 Dage efter kunde Gutfeld imidlertid indberette, at Drengen var Søn af Smeden i Nustrup og tjente i Ørderup. Det var hans Moder, som havde ledsaget ham, og hans Moster boede $\mathrm{i}$ Aabøl, men hverken hun eller hendes Mand havde netop hin Søndag været til Gudstjeneste, skønt de ellers var flittige Kirkegængere. Herredsfogden, Kancelliraad Zeuthen, undersøgte nu Sagen, og naar Amtet havde underrettet ham om Udfaldet og fældet Dom, vilde han lade Biskoppen dette vide.

Mere beretter de i Ribe Bispearkiv beroende Aktstykker ikke om Optrinet i Tirslund Kirke. Helt enestaaende har det for Resten ingenlunde været, hvad jo Bøndernes Holdning ogsaa tydeligt nok giver Udtryk for, thi der berettes om tilsvarende Scener fra andre Egne af Landet, hvor det dog havde været Kvinder, som underkastede sig Kuren. Det var saaledes Tilfældet i Tilst ved Skanderborg $\left.1751,{ }^{3}\right)$ men Kancelliet, der blev underrettet om Sagen, synes at have ladet sig nøje med at befale

2) Biskoppens Kopibog 1/5 1766 (Ribe Bispearkiv).

3) Kirkehist. Sam1. 6 - VI - 582 ff. 
Stiftsøvrigheden at drage Omsorg for, at sligt ikke oftere hændte, men om det skete, da straks at indberette det til „vederbørlig Strafs Lidelse af den skyldige“. 1783 stod en 13-aarig Pige fra Bregentved anklaget for Retten for at have foretaget den omtalte Handling, men Kongen resolverede, at hun kun skulde have Fængsel paa Vand og Brød i 4 Dage, mens den Kone, der havde været hendes Raadgiver, fik 14 Dage.")

Antagelig kan man herudfra slutte, at Smedesønnen fra $\mathrm{Nu}-$ strup er sluppet med en mild Straf.

4) Danske Studier 1920, S. $152 \mathrm{ff}$. 